\title{
Exploration of the Personal Memmorate of a Local Myth Based on Oral Genre Analysis
}

\section{Israt Jahan Lipa*}

Dept. of Anthropology, Comilla University, Comilla-3506, Bangladesh.

*Correspondence: isratjahan.lipa99@gmail.com (Israt Jahan Lipa, Lecturer, Department of Anthropology, Comilla University, Comilla-3506, Bangladesh).

\begin{abstract}
The conversational genres are part of and performed in everyday life, the culture of everyday talk, and the type of discourses embedded in ongoing social processes. Studying the communication and performance of ordinary people is essential to understand the discourses and to hear the unheard voices in our society. These are individual narratives usually composed orally by the tellers based on real incidents and personal experiences. Myths are important to be studied out to analyze discursive changes and locate personal experiences within the society. The importance of this local myth as an oral genre can be illustrated by analyzing their presence, practices, and functions within the community. For example, this local myth provides a useful narrative of cultural norms, changes in living conditions, and the world view of the local inhabitants. This paper is written following the personal memmorate analysis and it is analyzed based on oral genre analysis. It is explored that local people perceive this myth in their daily experiences and it guides their action.
\end{abstract}

Keywords: Myth, Memmorate, Exploration, Personal narratives, Inhabitants, and Oral genre analysis.

\section{INTRODUCTION:}

In almost every society myth exists and is seemed as a basic constituent of human culture (Butler, 1982). Myths are specific accounts of religious or ideological belief involved in extraordinary events or circumstances in a time that is unspecified but is understood as existing apart from ordinary human experience (Jung, 1998). In some senses, myths are an indispensable part of human culture. Into the structure of myth, it can be found as touching the psychological waves of the human mind.

According to Lauri Honko,

"A myth expresses and confirms society's religious values and norms; it provides patterns of behavior to be imitated, testifies to the efficacy of ritual with its practical ends and establishes the sanctity of cult" (Honko, 1972).

Beliefs centered on religious phenomena can be found quite significant in the socio-cultural setting of Bangladesh. The majority of people in this country are found having a strong grasp in diverse religious beliefs which play a significant role in their daily interactions. Here, religion guides their way of dealing with social issues and everyday actions. In this paper a myth believed in my community is narrated by illustrating its socio-cultural context and the local interpretation of this myth. It can also be considered as one of my personal experience narratives as I live in this same community and since childhood, I've heard this story. 
Herewith, I documented community people's narratives regarding the myth. The local narratives of this myth illustrated in the paper were collected by me from my family members and neighbors who live in the same community. These narratives have some religious meanings in the mind of local people which are perceived by them and it can be classified as a myth that exhibits some mythical characteristics like belief in supernatural things, belief related to God, sacred and profane dichotomy following individual phenomenological explanations.

This research was conducted in Cumilla City. Within this study area, the sample population was identified, and was studied during the research work. Semistructured interviews were conducted to collect the primary data. Collected data were interpreted using the most narrative words, and following the thematic analysis technique, primary data were analyzed. It was mostly based on personal experience narrative regarding a myth and the stories were analyzed based on oral genre analysis by Lauri Honko, (1972).

\section{Local Myth and Its Analysis}

Nearby my house, approximately within $2 \mathrm{~km}$ from my house there's a road which is believed 'supernatural' or 'sacred/ pious'. In my locality, this road is perceived as something different from other roads as it holds a specific religious meaning for the local people. It is believed that there was a very old graveyard here and many years ago by demolishing the graveyard a road was built in this area. This road was built for the community people so that they can enjoy a smooth connecting road to the main road for their better communication. But it is told in the community that from that time local people nearside this road experience different super natural issues while passing by this road. This feeling made this road religiously significant and community people perform some religious activities like using sacred charm and saying prayer while passing this road. I myself also heard this since my childhood and found that local people perceive this spot as 'supernatural' where some incidents happen frequently like seeing someone standing in the middle of the road and suddenly he vanishes out, facing road accidents while passing by this road or feeling scary or shivering when passing this road. In fact, when I also pass this road, I feel scared thinking of others stories that they experienced and shared with us within the community. Though many of the community people witnessed such supernatural incidents, I've never faced any sort of these. It is told that the early ancestors of this community were buried down in that graveyard which was demolished and now it's a road! There is a common belief amongst the community people that the souls of ancestors after death usually free themselves from the earthly relations and gain some supernatural power. When their graveyard was demolished and the graveyard was transformed into the road than the spirits of these ancestors got offended and that's why if someone passes this road wearing impure clothes, being impure, screaming or quarreling with others, hitting someone in this spot, driving with a high speed, or passing by drinking alcohol then they may face accidents in this road or something bad occurrence happen to them.

Most of the community people, pedestrians, and vehicle drivers consider this road as a religiously signified or supernatural spot because in the sociocultural context of Bangladesh graveyard is considered religiously as the sacred place. According to them, as this road has religious and cultural value, this road should be treated as a sacred place. The existence of an early graveyard is regarded as a responsible factor for which local people termed this road as a supernatural or sacred one. People say that this road has divine power and that's why everyone in the community, as well as people from the nearby community, treats this road as a sacred one. It is also practiced in the community that local people show respect while passing this road where once graveyard existed. Because they heard about the religious significance of this road from their ancestors and their ancestors held respect in their mind for this spot. One community people shared his belief, "I've heard about the power of this road from my grandparents. They told that they have seen their parents and grandparents saying a prayer when they pass this road. My grandparents always told us to show respect to this place as it is a sacred place. They also narrated about many accidents that happen on this road or within $1 \mathrm{~km}$ of this spot. They told us that because of the holy significance of 
this spot drivers also respect this place. And when drivers do something bad in this place like overtaking the car, driving with high speed, disobeying this place then an accident occurs. Really it is a holy place and everybody respects this place."

This narrative of a community people stated that this belief of presence of 'kobors than' (graveyard) and its link to road crash causation is believed from early ancestors of this area and this story orally passed away from generation to generation. And as such people seemed to be very attached to this myth in their everyday interactions. It is found as an integral oral narrative of this community which has an extensive oral tradition and religious significance for many years.

This myth is believed in my community where the community groups interpret and perceive it from their sociological and psychological aspect. It's their communal belief and practiced in the community for years. On that note, it can be argued that this myth at its most basic level is a narrative used by many different individuals within the society to illustrate abstract concepts such as fear of God, the existence of spirit, supernatural beings through characters and situations that ones can identify with. Thus this local narrative historically turns out as a myth that shares some common values and religious norms in this specific community's culture. And literature also suggests that once a group of individuals identifies and agrees upon certain desirable modes of behavior, derived from shared values and goals, a culture has begun to form (Leonard and McClure, 2004).

It can also be regarded as a myth following the four criteria proposed by Honko, (1972): form, content, function, and context. In terms of its form where a myth needs to be a narrative which provides a verbal account of what is known of sacred origins, there this narrative posits the idea of sacredness like using sacred charm in hand or neck, consider this spot as religiously sacred, facing trouble if one stays impure and follow some religious norms when passing this road. Regarding its content, these beliefs and modes of actions of community members can be understood as a certain narrative content that can be considered to critically analyze the socio-cultural background of the UniversePG I www.universepg.com community. In addition to these, it also describes how this myth is transmitted in speech, thought, and other modes of behavior.

Regarding its function, this myth has some social functions like it can be generalized that it offers both a cognitive basis for and practical models of behavior of an individual from the community. From this point of view, it can be characterized as ontological: it is incorporated and integrated into a coherent worldview of the local people and they perceive it as an important aspect of life and religion. Along with this, the context of this myth is, in normal cases, a pattern of behavior like how the community people perceive it as sacred and supernatural and what do they do to prevent them from any bad occurrence following their cultural norms and values.

According to community people;

"We recite many prayers and use sacred charm to keep us safe when we pass this road. Since childhood, we got to know that we can be punished here in form of accidents if we do any wrong deeds. This place is a symbol of our rewards of good or bad deeds what we do in our daily lives" (Interview with a local people).

Following this quote, it can be noted that this myth provides the ideological content for a sacred form of behavior which brings the creative events of the beginning of time to life. Along with these four criteria, hereby I would like to point out the dimensions of this myth following the aspects of Honko as conceptualizing this myth as a source of cognitive categories, a form of symbolic expression of belief, projection of the subconscious state of mind, charter of behavior, mirror of culture and social values, result of the historical situation and also a religious communication among group members (Honko, 1972; Saha, 2020).

It is demonstrated that community people regard this road as religiously sacred and something supernatural because they learned its story from their grandparents or seniors of their family. I also got to know the history of this road from my great grandmother. She told that in her childhood she observed her parents and other community people treating this place as a sacred one 
which has religious significance to them. While sharing her experience, she narrated one of her stories;

"One day when I was passing by this road alone in the afternoon then I saw a man who was passing this road along with me. But after sometime when I looked back, I found no one was there. The man was lost in the air suddenly. He faded out. I was much horrified and after that incident whenever I passed this road I remained terrified and tried to pass this road in rush. Since then, I started to use a sacred charm in my neck given by my grandmother to protect myself from any bad incidents while passing this road."

Like this experience, the narratives of this myth about this road is passed and shared from generation to generation. Also in the present-day, the story of this road is narrated in group gathering and within family time. Historically, it is shared that earlier there remained a graveyard and because of road maintenance and road construction now graveyard does not exist. Community people and vehicle drivers believe that because of demolishing the earlier graveyard for constructing the road, now something supernatural and accident occurs in this spot as it made offended to the pious spirits of the graveyard. This is shared regularly in daily conversation among the people of the community. Like, when an accident happens on this road then community people start sharing their experiences and the stories which they heard from their ancestors and this gossiping continues for a long time. Along with this, among cohorts, storytelling groups, religious performances like annual worship, annual festive the mythical stories of this road are told and shared. If anyone from outside of the community or new in the community hears the story of this road at first he may think it as 'superstitious' but for the community people, it's something sacred, super natural, and religious. It is their communal belief and Carl Jung also noted this form of communal behavior as 'collective unconsciousness.' He states that myths are expressions of the collective unconsciousness, in that they express core ideas that are part of their everyday interactions (Jung, 1998).

This myth can also be conceptualized as the collective form of narratives lying in the unconscious mind of community people for many days. It expresses the UniversePG I www.universepg.com communal ideas and values regarding this road and myth can be considered as a traditional tale with secondary, partial reference to something of collective importance (Burkert, 1982).

It seems that the notion of interpreting this road as sacred and supernatural is rooted in peoples' belief in religious sacredness and tradition. Herewith, the notion of perceiving this road as a religious one is rooted in their sense of sacredness and about their thoughts of the afterlife. They believe that this road should be passed in a religious way like weaving salam (a religious form of greeting someone), saying a prayer, remembering God while passing it to evade any bad happenings. Community people say dua (recitation from the holy book) and seek blessing from their ancestors when they pass this road. They believe that $d u a$ and blessing can prevent them from a bad occurrence. It is told in the community that those who do not say dua or do not take blessing from their ancestors met with unwanted happenings like accidents because some sort of divine power works on them at that time. It is also believed that those people who do not respect this spot and do not say a prayer and stay impure while passing this, they are cursed. Then they face accidents or anything bad happens in their life very soon after they pass it. Local people firmly claim that they witnessed such incidents many times in their life. It denotes the religious value of the community people which is very sensitive in the socio-cultural context of Bangladesh. Here religious values and norms are practiced with great importance and people have a strong grasp on their religious beliefs.

The social interaction of this myth cans also beanalyzed in light of Durkheim's perspective on the communal experience of a social fact. Durkheim, (1915) claims that communal sentiments are born out of communal experiences and herewith the belief of the existence of supernatural beings in this road leads others to adopt the religious norm of showing respect to this place to feel secured and safe from any unwanted occurrence. And the way of interpreting it from a communal aspect as a supernatural spot reflects the experiences of local people (seeing someone on the road at midnight, seeing someone passing there and suddenly vanished out, facing the road, falling down the car or getting fire in the vehicle). On that note, the 
notion of perceiving this spot seems quite symbolic for the community in nature. Whereas this same place can be exemplified or described in different aspects from an outsider's point of view, but from insiders eyes this place is seen as spiritual and cognitive one which is religiously significant and meaningful in the daily interaction of the community people. In response to this view of seeing myth as a charter of behavior, Bronislaw Malinowski's notion towards perceiving myth can be described. He claimed that myths must have a practical function in the society and myth often serves as a justification and validation of social and religious realities. Thus myth is a functional tool to deal with the social interactions of everyday life (Malinowski, 1922).

\section{DISCUSSION:}

This analysis of interpreting this road from different aspects clearly indicates that people interpret one object considering their socio-cultural context, behavioral responses, experiences and most importantly valuing their beliefs and practices. As such it can be explored differently in nature where cultural meaning and traditions, as well as history, play an important role. Because community people having specific cultural or religious beliefs about this spot consider themselves powerless in the face of uncontrollable and unexpected events frequently happen in this spot. They find themselves to be helpless concerning the spiritual energy of dead people when they pass this road.

On that note, it can be asserted that personal beliefs can influence the intensity of the sense of risk as well as the causal explanation that one may give for a specific event of his life. And this story turns out as a myth in the community because of its mythical characteristics in terms of its form, content and context. Interestingly, this myth also drives local people's attention towards a different explanation of road crash causation based on their religious and supernatural beliefs. Therefore, community people believe that any bad occurrence or accidents in this spot cannot be prevented as it occurs because of the spiritual presence of some pious persons who were the ancestors of this community and also for the existence of a graveyard which is considered as a holy place in community culture.

UniversePG I www.universepg.com
Apart from this road, in Bangladesh, some other places are also considered as spiritual, sacred, or supernatural spots. These places have some supernatural stories shared within the local communities and also have specific cultural meanings. In some sense, some of the stories of these places turn out as myths in categorical nature. Because of the concept of being sacred places, these spots bear different significance in the eye of local people from other places. And, in general, local people believe that in front of such spots or beside such spots something unexplained or supernatural issues occur because the whole environment of these spots hold a sacred or pious feeling and if anyone disrupts this environment or do something unlawful or sinful acts, then they are punished in form of some bad occurrences.

Hereby, the notion of this psychological interpretation of this sacred felt environment surrounded by these spots can be illustrated following the idea of Suzi Jones. Jones, (1976) states that not only can a myth be made meaningful by the psychological inclusion of the local environmental detail, but the surrounding environment centered on the myth can be imbued with psychological meaning by the mythological traditions of a group within a specific cultural boundary.

\section{CONCLUSION:}

Finally, it can be summed up like, what an individual perceives to be real at any given moment is indeed, to that individual, real. The myth illustrated above is a psychological myth in categorical form and local people have a strong grasp to narrate and perceive this for many years. It follows that the effect of this myth on what local people believe individual and collectively, influence their thoughts and perceptions; therefore their social realities. They tend to make sense of their surroundings; their interactions and relationships with the myth of this road. And this narrative explains the basic cultural and religious norms which are constructed in a manner that can be understood and identified with the group belief. It follows that the effects of the beliefs held by a group of people reflect the socio-cultural reality of a specific community which is far more influential to analyze the folk beliefs of a group. 


\section{ACKNOWLEDGEMENT:}

I would like to acknowledge the primary respondents of the paper. They are the prime informants and without their narratives, this paper wouldn't be informative. So, I express my gratitude to them because of their support, time and information.

\section{CONFLICTS OF INTEREST:}

This paper is written solely by the author and the information was also collected by me personally. There's no issue and conflicts regarding funding and authorship of the paper. As it's my personal work so there's no conflict of interest in any sort regarding the paper.

\section{REFERENCES:}

1) Burkert, Walter. (1982). Structure and History in Greek Mythology and Ritual. University of California Press. ISBN 0520047702, 9780520047709.

https://www.ucpress.edu/book/9780520047709/s tructure-and-history-in-greek-mythology-andritual

2) Durkheim, Émile. (1915). The elementary forms of the religious life, a study in religious sociology. London: New York: G. Allen \& Unwin; Macmillan. ISBN 0-19-954012-8.
3) Honko, Lauri. (1972). The Problem of Defining Myth. Finnish Society for the Study of Comparative Religion. Indiana University. https://doi.org/10.30674/scripta.67066

4) Jones, Suzi. (1976). Regionalization: A Rhetorical Strategy. Folklore Institute Journal, 13(1): p.105. https://doi.org/10.2307/3813817

5) Jung, G. Carl. (1998). Jung on Mythology. Princeton University Press. Volume 2. https://doi.org/10.2307/j.ctv10crg5b

6) Leonard, S. and McClure, M. (2004). Myth \&knowing: An introduction to world mythology, Chapter 1. The McGraw-Hill Companies, Ney York. ISBN-13: 9780767419$574 \mathrm{y}$.

7) Malinowski, B. (1922). Argonauts of the western Pacific: An account of native enterprise and adventure in the archipelagoes of Melanesian New Guinea. London: G. Routledge \& Sons. https://doi.org/10.4324/9781315772158

8) Saha KK. (2020). Dependency among Kautilya's three major ideas: Upaya, Sadgunya, and Prakrti, Br. J. Arts Humanit., 2(2), 24-35. https://doi.org/10.34104/bjah.020024035

Citation: Lipa IJ. (2020). Exploration of the personal memmorate of a local myth based on oral genre analysis, Br. J. Arts Humanit., 2(5), 95-100. https://doi.org/10.34104/bjah.0200950100 @) क 